\title{
INFLUENCE OF CYMIAZOLE HYDROCHLORIDE ON MITOTIC AND PROLIFERATIVE ACTIVITIES OF CULTURED HUMAN LYMPHOCYTES
}

\author{
STANIMIROVIĆ Z*, TODOROVIĆ DAJANA*, STEVANOVIĆ JEVROSIMA*, MLADENOVIĆ M**, \\ JANKOVIĆ LJILJANA*** and ĐORĐEVIĆ $M^{\star * * *}$ \\ * Department of Biology, Faculty of Veterinary Medicine, Belgrade, ** Faculty of Agriculture, \\ Belgrade-Zemun, ${ }^{* * *}$ Department of Zoohygiene, Faculty of Veterinary Medicine, Belgrade
}

(Received 11. November 2002)

Cymiazole hydrochloride is the active ingredient of a synthetic, systemically acting acaricide used in beekeeping (Apitol ${ }^{\circledR}$, Apichem $^{\circledR}$ ). Considering that residues of cymiazole hydrochloride were detected in all bee products being used for human nutrition and as alternative medications in human and veterinary medicine, the objective of this study was to evaluate the effects of cymiazole hydrochloride on mitotic activity of cultured human lymphocytes. The mitotic and proliferation indices in phytohaemagglutinin-activated human peripheral blood lymphocytes were determined using three experimental concentrations of cymiazole hydrochloride $(0.01 ; 0.1 ; 1 \mathrm{mg} / \mathrm{ml})$. All experimental concentrations of cymiazole hydrochloride increased mitotic index values (MI) by a statistically highly significant amount $(p<0.001)$. Moreover, proliferation in$\operatorname{dex}(P I)$ was also changed very significantly $(p<0.001)$ after each experimental cymiazole hydrochloride treatment.

The dose dependent increase in proliferation index values clearly demonstrates the ability of cymiazole hydrochloride to induce significant alterations of cell cycle kinetics, having an influence on GO state and arousing cell division. This indicates a risk from consuming bee products with cymiazole hydrochloride residues, particularly in those predisposed to malignant diseases. Strict respect to the withrawal time while using cymiazole hydrochloride $\left(\right.$ Apito $^{\circledR},{ }^{\circledR}$, pichem $\left.^{\circledR}\right)$ is of great importance because residue levels higher than the permitted one can easily occur in honey and other bee products from treated honey bee colonies.

Key words: cymiazole hydrochloride, mitotic index, proliferation index, honey bee, varroasis, human lymphocytes.

\section{INTRODUCTION}

Cymiazole hydrochloride is an iminophenyl thiazolidine derivative, active against acari (mites and ticks). In veterinary medicine, cymiazole hydrochloride is recommended for the control of varroasis in honey bees. The intended pharmaceutical formulation, $17.5 \%$ granulate of cymiazole hydrochloride, is dissolved in 
water to obtain a $0.35 \%$ aqueous solution. The freshly prepared solution is applied either topically (as a drip on to the beeways) or orally (mixed into the winter feed for bees). Doses of twice $100-350 \mathrm{mg}$ cymiazole hydrochloride per hive (25 $35 \mathrm{mg} /$ occupied beeway) at a 7 day interval are recommended for topical administration. In the winter feed approximately $500-700 \mathrm{mg}$ cymiazole hydrochloride are administered per hive (50-70 mg/occupied beeway). Cymiazole hydrochloride is the active ingredient of Apitol ${ }^{\circledR}$ and Apichem ${ }^{\circledR}$, which are synthetic, systemically acting acaricides.

After administration of cymiazole hydrochloride either by dripping an aqueous solution on the bees or offering the bees medicated feed, homogenous distribution within the bee colony is assured by the bee's social behaviour (feed exchange and cleaning activities). Cymiazole hydrochloride, which is systemically active against the sucking mites, is transferred from the digestive tract to the haemolymph (blood) of the bee. Varroa mites living on the bee are then immediately killed.

The treatment of honey bee colonies with acaricides influences the quality of bee products. Cymiazole hydrochloride especially endangers the quality of honey, since this substance is water-soluble and thence, easily diluted in honey. Use of this substance during the nectar flow always results in considerable amounts of residues.

Residues of cymiazole hydrochloride can be detected not only in honey bees, but in honey, beeswax and other bee products, too (Eyrich and Ritter, 1986; Eischen et al., 1988; Patetta and Manino, 1988; Eyrich and Ritter, 1990; Cabras et al., 1993; Cabras et al., 1994; Bogdanov et al., 1998; Volante et al., 2001; Korta et al., 2001; Korta et al., 2002). Considering that cymiazole hydrochloride residues may be ingested by consumers of bee products, it is very important to evaluate the influence of cymiazole hydrochloride on mitotic and proliferative activities of cultured human lymphocytes.

The ability of cymiazole hydrochloride to induce numerical and structural chromosomal changes, as well as to increase sister chromatid exchange (SCE frequency) indicate the genotoxic and mutagenic properties of this drug (Stanimirović et al., 2001).

\section{MATERIAL AND METHODS}

Test substance and controls. Cymiazole hydrochloride (Apitol ${ }^{\circledR} \mathrm{JKL}: 03$ 6, 6/005-011/005; Evrotom, Ruma, Yugoslavia) was used as the test substance. The positive control was cyclophosphamide (Sigma Chemical Co., St. Louis, MO) at a final concentration of $40 \mu \mathrm{g} / \mathrm{ml}$. The negative control was $0,9 \% \mathrm{NaCl}$.

Lymphocyte culture. Human peripheral blood lymphocyte cultures were prepared according to a slight modification of the protocol described by Evans and O'Riordan (1975). Heparinised whole blood samples $(0.8 \mathrm{ml})$ obtained from three healthy men under 35 years of age were added to vials with $9.2 \mathrm{ml}$ of prewarmed Parker 199 medium (Torlak, Belgrade, Yugoslavia) containing 30\% of inactivated calf serum (Serva, Heidelberg, Germany) and $0.04 \mathrm{mg} / \mathrm{ml}$ of phytohaemagglutinin (Murex Diagnostics Ltd., Dartford, England). At the beginning of incu- 
bation 5-bromo-2'-deoxyuridine (BrdUrd, Sigma Chemical Co., St. Louis, MO) was added to each culture to obtain a final concentration of $25 \mu \mathrm{M}$. Cultures were incubated in the dark for $72 \mathrm{~h}$ at $37^{\circ} \mathrm{C}$.

Treatment. Exactly $47 \mathrm{~h}$ and $30 \mathrm{~min}$ after the beginning of incubation cymiazole hydrochloride (Apitol ${ }^{\circledR}$ ) was added to cultivation vials in such amounts to obtain final experimental concentrations of: $0.01,0.1$, and $1 \mathrm{mg} / \mathrm{ml}$. Positive and negative controls were added in separate cultivation vials $(40 \mu \mathrm{g} / \mathrm{ml}$ cyclophosphamide and $0.9 \% \mathrm{NaCl}$ ).

Analysis of mitotic and proliferation indices. Two hours before harvesting, colchicine (Sigma Chemical Co., St. Louis, MO) was added to the cultures to achieve a final concentration of $0.5 \mu \mathrm{g} / \mathrm{ml}$. After standard chromosome preparation, microscopic slides were stained according to Ronne (1991). Mitotic index (MI) was determined on 1000 or more cells, whereas cell cycle kinetics were estimated from the proliferation index (Tice and lvett, 1985) scored on at least 200 metaphases per donor. Proliferation index $(\mathrm{PI})$ was calculated according to the formula:

$$
\mathrm{PI}\left(\mathrm{M}_{1}+2 \mathrm{M}_{2}+3 \mathrm{M}_{3}\right) / 100
$$

- $M_{1}, 2 M_{2}$ and $3 M_{3}$ refer to the percentage of metaphases in the first, second and third mitotic cycle.

Statistical analysis. Values obtained for MI and PI were analysed by Student's $t$-test and analysis of variance (ANOVA).

\section{RESULTS}

The basic parameters of descriptive statistics for the mitotic and proliferative indices are presented in Table 1 and Table 2. Considering that five different experimental cultures were examined (positive control - cyclophosphamide, negative control $-0,9 \% \mathrm{NaCl}$, and three cultures with the test substance - cymiazole hydrochloride in concentrations of $1 ; 0.1$ and $0.01 \mathrm{mg} / \mathrm{ml}$ ), the results of ANOVA showed statistically highly significant $(p<0.001)$ differences between the experimental cultures for both $\mathrm{MI}(\mathrm{F}=2303.48)$ and $\mathrm{PI}(\mathrm{F}=375.022)$.

The values obtained for $\mathrm{Ml}$ are presented in Table 3 and Figure 1. Cymiazole hydrochloride, both in the recommended treatment dose $(1 \mathrm{mg} / \mathrm{ml})$, as well as in doses ten times $(0.1 \mathrm{mg} / \mathrm{ml})$ and a hundred times lower than the therapeutic dose $(0.01 \mathrm{mg} / \mathrm{ml})$, induced statistically highly significant $(\mathrm{p}<0.001)$ increases in $\mathrm{Ml}(\mathrm{Ml}$ $=12.33 \%, 8.31 \% ; 7.35 \%$; respectively) in comparison to the negative control (MI $=5.47 \%$ ). However, cyclophosphamide at $40 \mu \mathrm{g} / \mathrm{ml}$ (positive control) was found to be the most efficient at increasing the Ml of human lymphocytes, causing the highest increase ( $\mathrm{Ml}=14.57 \%)$.

The values for the PI showed that all experimental concentrations of cymiazole hydrochloride induced statistically highly significant increase $(p<0.001)$, in comparison to the negative control $(\mathrm{Pl}=1.72)$. These increases depended on the increase of cymiazole hydrochloride concentration, being $\mathrm{PI}=1.83 \% ; 1.84 \%$ and $1.88 \%$ for concentrations of $0.01 \mathrm{mg} / \mathrm{ml} ; 0.1 \mathrm{mg} / \mathrm{ml}$ and $1 \mathrm{mg} / \mathrm{m}$, respectively). The highest increase $(\mathrm{PI}=2.00)$ was observed in the positive control (Table 3, Fig- 
ure 2). The dose dependent increase in PI (Table 3, Figure 2) clearly demonstrated that cymiazole hydrochloride caused significant alterations of cell cycle kinetics having an influence on the G0 state and arousing cell division.

Table 1. The basic values of descriptive statistics for the mitotic index after different treatments

\begin{tabular}{|c|r|r|r|r|c|}
\hline $\begin{array}{c}\text { Concentration of } \\
\text { cymiazole hydrochloride }\end{array}$ & Mean & Min & Max & SD & SE \\
\hline Negative control & 5.47 & 5.13 & 6.05 & 0.3494 & 0.0902 \\
\hline $1 \mathrm{mg} / \mathrm{ml}$ & 12.33 & 11.99 & 12.97 & 0.2517 & 0.0650 \\
\hline $0.1 \mathrm{mg} / \mathrm{ml}$ & 8.31 & 8.02 & 8.81 & 0.1989 & 0.0514 \\
\hline $0.01 \mathrm{mg} / \mathrm{ml}$ & 7.35 & 7.11 & 7.81 & 0.1850 & 0.0478 \\
\hline Positive control & 14.57 & 14.02 & 15.43 & 0.4429 & 0.1144 \\
\hline
\end{tabular}

Table 2. The basic values of descriptive statistics for the proliferative index after different treatments

\begin{tabular}{|c|c|c|c|c|c|}
\hline $\begin{array}{c}\text { Concentration of cymiazole } \\
\text { hydrochloride }\end{array}$ & Mean & Min & Max & SD & SE \\
\hline Negative controle & 1.72 & 1.695 & 1.79 & 0.0285 & 0.0073 \\
\hline $1 \mathrm{mg} / \mathrm{ml}$ & 1.87 & 1.830 & 1.91 & 0.0179 & 0.0046 \\
\hline $0.1 \mathrm{mg} / \mathrm{ml}$ & 1.84 & 1.830 & 1.88 & 0.0113 & 0.0029 \\
\hline $0.01 \mathrm{mg} / \mathrm{ml}$ & 1.83 & 1.820 & 1.86 & 0.0127 & 0.0033 \\
\hline Positive control & 1.99 & 1.965 & 2.03 & 0.0226 & 0.0058 \\
\hline
\end{tabular}

Table 3. Mitotic index and proliferative kinetics of cultured human lymphocytes treated with cymiazole hydrochloride

\begin{tabular}{|c|c|c|c|c|c|}
\hline \multirow{2}{*}{$\begin{array}{l}\text { Concentration of cymiazole } \\
\text { hydrochloride }\end{array}$} & \multirow{2}{*}{$\mathrm{Ml}(\%)$} & \multicolumn{3}{|c|}{ Percent cells in } & \multirow{2}{*}{$\mathrm{PI}$} \\
\hline & & M1 & M2 & M3 & \\
\hline Negative control & 5.47 & 32.63 & 57.77 & 7.23 & 1.72 \\
\hline $1 \mathrm{mg} / \mathrm{ml}$ & $12.33^{* * *}$ & 23.13 & 65.73 & 11.00 & $1.88^{\star \star \star}$ \\
\hline $0.1 \mathrm{mg} / \mathrm{ml}$ & $8.31 * * *$ & 25.77 & 64.31 & 10.03 & $1.84^{\star * \star}$ \\
\hline $0.01 \mathrm{mg} / \mathrm{ml}$ & $7.35^{\star \star \star}$ & 28.73 & 59.10 & 12.17 & $1.83^{\star \star \star}$ \\
\hline Positive control & $14.57^{\star \star \star *}$ & 13.50 & 73.50 & 13.03 & $2.00^{* \star \star}$ \\
\hline
\end{tabular}

MI - mitotic index;

M1, M2, M3 - refer to the percentage of cells in the first, second and third cycle;

$\mathrm{PI}$ - proliferation index;

$\mathrm{PI}=(\mathrm{M} 1+2 \mathrm{M} 2+3 \mathrm{M} 3) / 100$

*** $\mathrm{p}<0.001$ ( Student's $\mathrm{t}-$ test) 
Acta Veterinaria (Beograd), Vol. 53. No. 1, 47-55, 2003.

Stanimirović $Z$ et al. Influence of cymiazole hydrochloride on mitotic and proliferative activities of cultured human lymphocytes

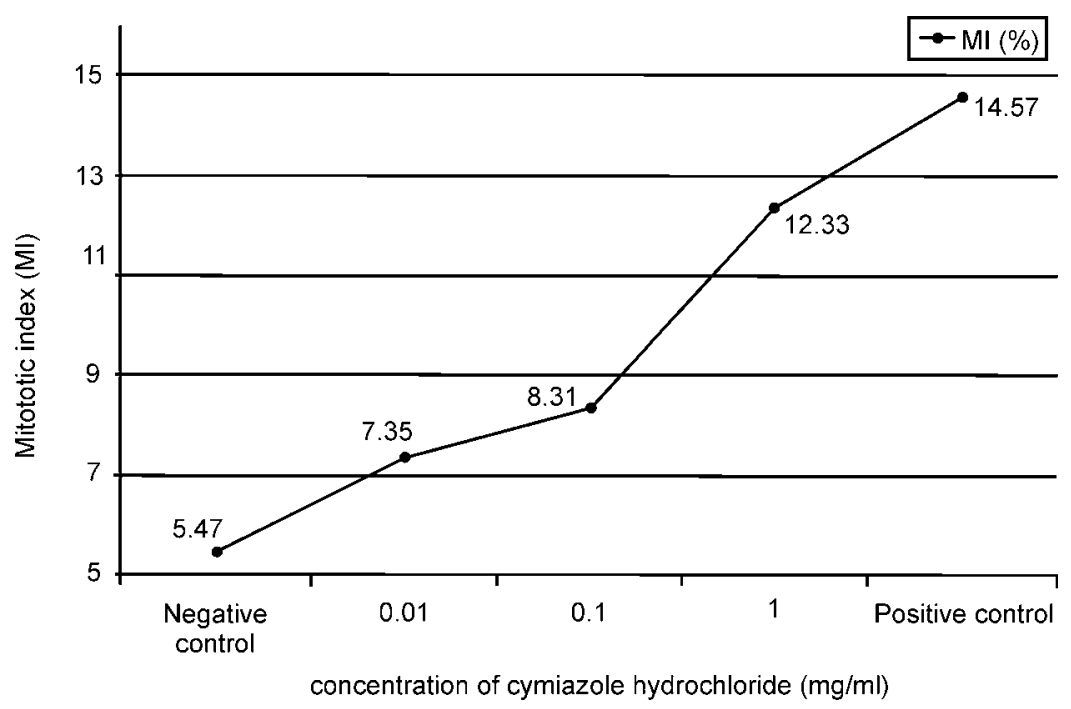

Figure 1. Mitotic index (MI) of cultured human lymphocytes in control and experimental cultures.

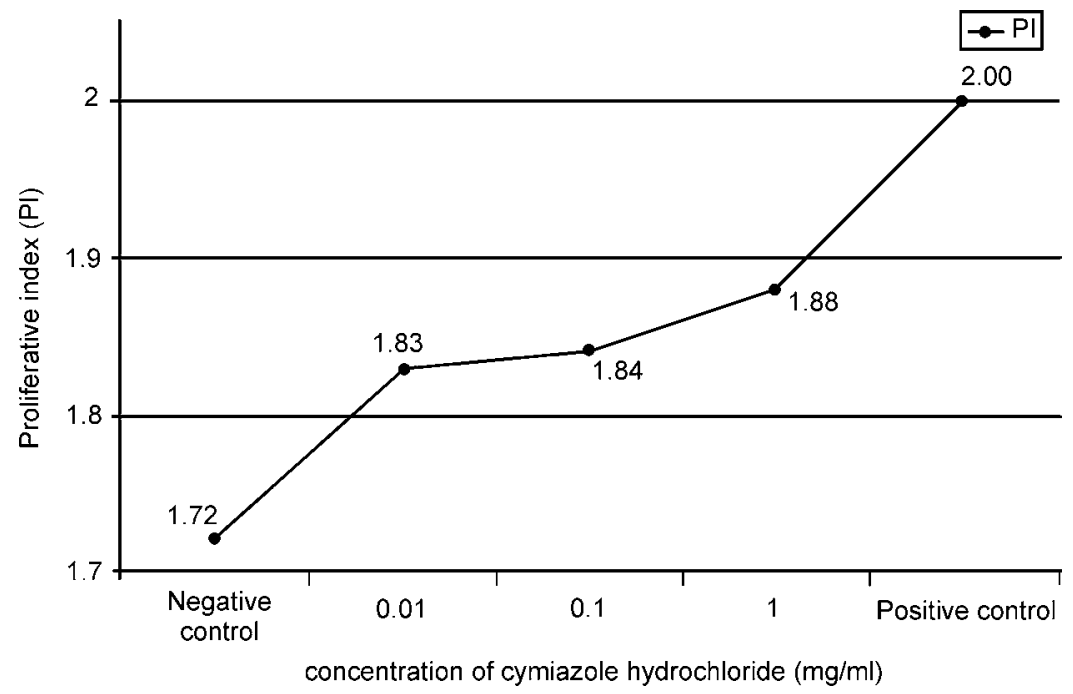

Figure 2. Proliferative index (PI) of cultured human lymphocytes in control and experimental cultures. 


\section{DISCUSSION}

In general, the use of varroacides in bee colonies leaves residues in various bee products. Hence, all around the world, maximum residue levels (MRL) for cymiazole hydrochloride in honey are determined for the purpose of consumer safety. They range from $0,01 \mathrm{ppm}$ in Italy and Germany to $1 \mathrm{ppm}$ in the EU. The US does not have an MRL for cymiazole hydrochloride in honey. No MRL's have been established for beeswax (Wallner, 1999).

Following drip-on treatment at the recommended dose, residues of cymiazole hydrochloride were found in the range of 0.01 to $1.1 \mathrm{mg} / \mathrm{kg}$ in honey, 0.2 to $9.3 \mathrm{mg} / \mathrm{kg}$ in honeycomb and 0.37 to $1.25 \mathrm{mg} / \mathrm{kg}$ in beeswax. The feeding method resulted in lower cymiazole hydrochloride concentrations in the range of 0.01 to $0.34 \mathrm{mg} / \mathrm{kg}$ in honey, 0.33 to $2.4 \mathrm{mg} / \mathrm{kg}$ in honeycomb and 0.3 to $1.02 \mathrm{mg} / \mathrm{kg}$ in beeswax (Committee for Veterinary Medicinal Products, 1996).

Cymiazole hydrochloride was found to be moderately toxic to honey bees when ingested at a rate of 3500ppm (Patetta and Manino, 1988). If fed to bees it reduced development of the hypopharyngeal glands and increased the amount and acidity of rectal contents (Omar and Shoriete, 1992).

Cabras et al. (1994) measured residues of cymiazole hydrochloride in honey bees and in honey. Cymiazole hydrochloride residues in unsealed honey decreased from an average $2.45 \mathrm{ppm}$ (after one-day treatment) to $0.14 \mathrm{ppm}$ (112 days after treatment), but in honey bees residues were $84.12 \mathrm{ppm}$ after one-day treatment but decreased to $0.07 \mathrm{ppm}$ after 15 days. Based on these results, the authors concluded that honey bees can rapidly degrade cymiazole hydrochloride, but that levels higher than the permitted $0.01 \mathrm{ppm}$ (in Italy) can easily occur in honey from treated colonies.

Kezic et al. (1992) investigated the influence of cymiazole hydrochloride on honey bee enzymes and affirmed that this drug, in the dose recommended by the producer, increased benzo-(a)-pyrene monooxidase activity by $300 \%$.

In previous investigations of the genotoxic effect of cymiazole hydrochloride on cultured human lymphocytes (Pejović et al., 1999; Pejovic et al., 2000; Stanimirović et al., 2001), the tested doses of that drug were lower than the therapeutic dose $(1 ; 0,1$ and $0.01 \mathrm{mg} / \mathrm{ml})$ and induced a significant frequency of structural chromosomal changes of the lesion and break types. Significant deviations in sister chromatid exchange (SCE) frequency were obtained in all experimental cultures. Moreover, the highest tested dose induced more than 13 exchanges per lymphocyte, compared to the control (about 2 exchanges per lymphocyte), while the middle and the lowest tested dose induced 8 and 5 exchanges, respectively. These results indicated significant genotoxic potential of cymiazole hydrochloride (the ability to disturb cell division and provoke tumours) and significant mutagenic potential (the ability to induce mutations of DNA) (Stanimirović et al., 2001).

The results of this study suggest caution in using cymiazole hydrochloride by strictly respecting the withrawal time, having in mind the finding of cymiazole hydrochloride residues in the range of 0.01 to $1.1 \mathrm{mg} / \mathrm{kg}$ in honey, 0.2 to 9.3 $\mathrm{mg} / \mathrm{kg}$ in honeycomb and 0.37 to $1.25 \mathrm{mg} / \mathrm{kg}$ in beeswax following the drip-on treatment at the recommended dose, as well as cymiazole hydrochloride concen- 
trations in the range of 0.01 to $0.34 \mathrm{mg} / \mathrm{kg}$ in honey, 0.33 to $2.4 \mathrm{mg} / \mathrm{kg}$ in honeycomb and 0.3 to $1.02 \mathrm{mg} / \mathrm{kg}$ in beeswax after the feeding method of administration (Committee for Veterinary Medicinal Products, 1996).

Strict respect for the withrawal time while using cymiazole hydrochloride is of great importance because, although honey bees can rapidly degrade cymiazole hydrochloride, residue levels higher than the permitted one can easily occur in honey from treated colonies (Cabras et al., 1994). Disrespect for the recommended doses of cymiazole hydrochloride and application rules can lead to disturbances in functioning of honey bee colonies by reducing development of the hypopharyngeal glands and increasing the amount and acidity of rectal contents (Omar and Shoriete, 1992) as well as increasing benzo-(a)-pyrene monooxidase activity by $300 \%$ (Kezic et al., 1992). Also, disrespect concerning directions for use could cause disarrangements in spermatogenesis and oogenesis in honey bees, as well as in consumers (Stanimirović et al., 2001).

The fact that all experimental concentrations of cymiazole hydrochloride $(0.01,0.1$ and $1 \mathrm{mg} / \mathrm{ml})$ significantly increased mitotic and proliferative activities of cultured human lymphocytes (Table 3, Figures 1, 2), i.e. influenced Go state and aroused cell division, suggest caution in the consumption of bee products (especially honey) from honeybee colonies treated with Apitol ${ }^{\circledR}$ or Apichem ${ }^{\circledR}$, particularly by those predisposed to malignant diseases.

\section{Acknowledgements}

These studies were supported by the Serbian Ministry of Science, Technology and Development, Grant No 1870.

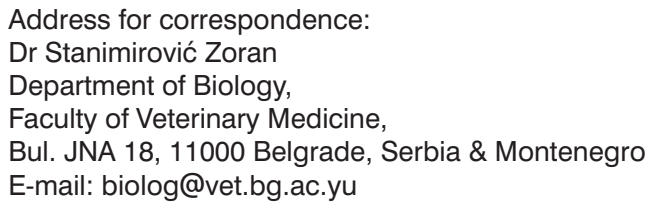

\section{REFERENCES}

1. Bogdanov S, Kolchenmann V, Imdorf A, 1998, Acaricide residues in some bee products, J Apic Res 37, 57-67.

2. Cabras $P$, Melis $M$, Spanedda $L, 1993$, Determination of cymiazole residues in honey by HPLC. $J$ AOAC 76, 92-3.

3. Cabras P, Martini MG, Floris I, Spanedda L, 1994, Residue of cymiazole in honey and honey bees. J Apic Res, 33, 83-6.

4. Committee for Veterinary Medicinal Products, Summary Report, Cymiazole. The European Agency for the Evaluation of Medicinal Products. Veterinary Medicines Evaluation Unit. EMEA/MRL/ 067/96-FINAL March 1996. http://www.fedesa.be/Events/Medaviability/013000en.pdf

5. Eischen FA, Cardoso-Tamez D, Dietz A, Ware GO, 1988, Cymiazole, a systemic acaricide that controls Acarapis woodi (Rennie) infesting honey bees. I. Laboratory tests. II. Apiary tests. Apidologie, 19, 4, 367-76.

6. Evans HJ, O'Riordan M, 1975, Human peripheral blood lymphocytes for the analysis of chromosome aberrations in mutagen tests. Mutat Res, 31, 135-48. 
7. Eyrich U, Ritter W, 1986, 39. Die Verteilung eines systemischen Akarizids im Körper dir honigbiene "The distribution of a systemic acaricide in the body of the honey bee". Apidologie 17, 4, 379-81.

8. Eyrich U, Ritter W, 1990, Distribution of a systematic functioning medicament in the body of the honey bee, Apis mellifera. Zeitschrift für Angewante Entomologie 109, 15-20.

9. Kezić $N$, Lucić $D$, Sulimanović $\boxminus, 1992$, Induction of mixed-function oxidase activity in honey-bee as a bioassay for detection of environmental xenobiotics. Apidologie, 23, 217-23.

10. Korta E, Bakkali A, Berrueta LA, Gallo B, Vicente F, Kilchenmann V, Bogdanov S, 2001, Study of acaricide stability in honey. Characterization of amitraz degradation products in honey and beeswax. J Agric Food Chem 49, 5835-42.

11. Korta E, Bakkali A, Berrueta LA, Gallo B, Vicente F, 2002, Study of an accelerated solvent extraction procedure for the determination of acaricide residues in honey by high-performance liquid chromatography-diode array detector. J Food Prot 65, 161-6.

12. Omar MOM, Shoriete MN, 1992, Effect of the systemic acaricide "Apitol" on some physiological characters of honey bee worker, Assiut J Agricul Sci 23, 4, 203-15.

13. Patetta A, Manino A, 1988, Examination of the action on honey bees of chemicals used in the control of Varroa jacobsoni, Apicoltore Moderno 79, 3, 109-14.

14. Pejović $D$, Stanimirović Z, Jovanović $N, 1999$, Apitol ${ }^{\circledR}$ - genotoxic and mutagenic potential? Abstracts from EEMS-99 (29 ${ }^{\text {th }}$ Annual Meeting of the European Environmental Mutagen Society) Vol 85, Suppl I, July 4-9, pp 45. Copenhagen, Denmark.

15. Pejović D, Stanimirović Z, Đelić N, Raičević Nevena, 2000, Indirect and direct effects of the application of Apitol ${ }^{\circledR}$ in varoosis control in honeybees, In: Trailović D, Lazarević M, editors, Proceedings of the 2nd Symposium in Animal Clinical Pathology and Therapy Clinica Veterinaria 2000 June 12-16, pp 231-234. Budva, YU.

16. Ronne M, 1991, High resolution banding present aspects. Gen Sel Evol 23 suppl. 1, 49s-55s.

17. Stanimirovic Z, Stevanovic Jevrosima, Mladenovic M, 2001. Apitol - antivarootic of the first choice-yes or no? Book of abstracts. The $2^{\text {nd }}$ international exhibition "INTERMIOD-2001", Sept 14, pp 202-203. Moscow, Russia.

18. Tice RR, Ivett JL, 1985, Cytogenetic analysis of bone marrow damage, In: Irons RD, editor, Toxicology of the Blood and Bone Marrow, Raven Press, New York, 119-40.

19. Volante M, Galarini R, Miano V, Cattaneo M, Pecorelli I, Bianchi M, Cossignati L, Damiani P, 2001, A Spme - GC - MS approach for antivarroa and pesticide - residues analysis in honey. Chromatographia 54, 3-4, 241-6.

20. Wallner K, 1999, Varroacides and their residues in bee products. Apidologie 30, 2-3, 235-48.

\title{
UTICAJ CIMIAZOL HIDROHLORIDA NA MITOTSKU I PROLIFERATIVNU AKTIVNOST U KULTURAMA HUMANIH LIMFOCITA
}

\author{
STANIMIROVIĆ Z, TODOROVIĆ DAJANA, STEVANOVIĆ JEVROSIMA, MLADENOVIĆ M, \\ JANKOVIĆ LJILJANA i ĐORĐEVIĆ M
}

\section{SADRŽAJ}

Cimiazol hidrohlorid predstavlja aktivnu supstancu sintetičkih akaricida sa sistemskim dejstvom koji se koriste u pčelarstvu (Apitol ${ }^{\circledR}$, Apichem $\left.{ }^{\circledR}\right)$. Obzirom da su rezidue cimiazol hidrohlorida detektovane u svim pčelinjim proizvodima, koji se koriste u ishrani i kao alternativni lekovi u humanoj i veterinarskoj medicini, cilj ovog rada bio je ispitivanje efekata cimiazol hidrohlorida na mitotsku i proliferativnu aktivnost humanih limfocita u kulturi. Analizirani su mitotski i proliferativni in- 
Acta Veterinaria (Beograd), Vol. 53. No. 1, 47-55, 2003.

Stanimirović Z et al. Influence of cymiazole hydrochloride on mitotic and proliferative activities of cultured human lymphocytes

deksi humanih limfocita aktiviranih fitohemaglutininom pri čemu su koršćene tri eksperimentalne koncentracije cimiazol hidrohlorida u opsegu od $0.001 \mathrm{mg} / \mathrm{ml}$ do $1 \mathrm{mg} / \mathrm{ml}$. Sve tri eksperimentalne koncentracije cimiazol hidrohlorida izazvale su vrlo visoko signifikantno $(p<0.001)$ povećanje vrednosti mitotskog indeksa (MI) humanih limfocita. Takođe, vrednosti proliferativnog indeksa (PI) su vrlo visoko signifikantno $(p<0.001)$ povećane nakon svakog eksperimentalnog tretmana cimiazol hidrohloridom.

Dozno zavisno povećanje vrednosti proliferativnog indeksa jasno pokazuje sposobnost cimiazol hidrohlorida da izazove značajne promene u kinetici ćelijskog ciklusa utičući na G0 tačku i podstičući ćelijsku deobu, što ukazuje na rizik prilikom konzumiranja pčelinjih proizvoda sa reziduama cimiazol hidrohlorida, posebno kod jedinki sklonih malignitetima. Izuzetno je značajno strogo poštovanje karence prilikom upotrebe cimiazol hidrohlorida (Apitol ${ }^{\circledR}$, Apichem ${ }^{\circledR}$ ) jer rezidue, u količini većoj od dozvoljene, mogu veoma lako dospeti u med i druge pčelinje proizvode dobijene od tretiranih pčelinjih društava. 